\title{
On a new Monogenean-ectoparasites Neocalceostoma guptai n. sp. from gills of fresh-water cat fish Mystus seenghala (Ham.) of District Ayodhya (Faizabad), Uttar Pradesh, India
}

\author{
Surya Prakash Mishra
}

Department of Zoology, Ganpat Sahai Post Graduate College, Sultanpur, Uttar Pradesh, India.

To Cite this Article

Surya Prakash Mishra, "On a new Monogenean-ectoparasites Neocalceostoma guptai n. sp. from gills of fresh-water cat fish Mystus seenghala (Ham.) of District Ayodhya (Faizabad), Uttar Pradesh, India", International Journal for Modern Trends in Science and Technology, Vol. 07, Issue 02, February 2021, pp.-09-12.

Article Info

Received on 12-January-2021, Revised on 26-January-2021, Accepted on 29-January-2021, Published on 01-February-2021.

\section{ABSTRACT}

The fresh-water cat fish Mystus seenghala (Ham.) was collected from local fish market of district Faizabad presently known as Ayodhya (U.P.) and examined 25 specimens, of which only 02 specimens were found infected with 08 specimens of said species. The sites of infections being gill filaments of the host. There are three species of the genus Neocalceostomawas discovered earlier viz.Neocalceostoma elongatum; Neocalceostoma microformis and Neocalceostoma chauhani. The present form differs from all the known species. It differs from Neocalceostoma microformis and Neocalceostoma chauhani in having larger body, difference in ratio of haptor and body, difference in shape of cirrus and gonads. The present form also differs from Neocalceostoma elongatum in having different shape of haptor, absence of oesophagus and difference in shape of cirrus. The present form is therefore, described as a new species Neocalceostoma guptai $n$. sp. named in honor of Dr. S. P. Gupta for his valuable contribution in the field of taxonomy.

Key words: Monogenean-ectoparasites; Mystus seenghala; Neocalceostoma guptai.

\section{INTRODUCTION}

Monogeneans are mainly ectoparasites of fishes but occasionally they are found as endoparasites (Gussev and Fernando, 1973). Among parasites infecting fishes, the monogeneans constitute a group,commonly they occur as ectoparasites on the gills and skin of fishes and lower aquatic invertebrates. Monogenean are browsers that move about freely on the fish's body surface feeding on mucus and epithelial cells of the skin and gills; however, a few adult monogenean will remain permanently attached to a single site on the host(Agarwal and Pandey, 1981). Monogenean undergo asexual mode of reproduction and multiply rapidly to form dense population on the gills of the host (Agarwal, and Misra, 1994). The population structure of this monogenean, however, depends on a wide range of environmental factors; the relative importance of these factors varies from species to species and also within the same species depending on the host taxonomy and the nature of habitat (Gupta, 1975; Chubb, 1977; Agarwal and Singh, 1985).

Monogenean constitutes a group, which play an important role as pathogens of severe diseases (Hoffman, 1979; Srivastava, 1980). This is because they affect those organs and tissues which are vital to the normal functioning such as gills and skin, the organs of respiration (Mishra, 2007, 2014a). In majority of cases, monogenean cause 
dual type of injury to their hosts. Through their hooks and other organs of attachment, they break the continuity at the site of attachment and result is to localize hemorrhage (Mishra, 2008, 2014b and 2021a). Monogenean infestations cause irritation and excessive mucus production and create an opening for bacterial invasion (Mishra, 2020a). A few monogeneans on a healthy mature fish are not usually significant; however, moderate numbers can cause significant mortalities (Pandey and Mehta, 1986; Mishra, 2021b). When fish are exposed to environmental or behavioural stressors, the potential damage from monogenean is greater. Prevention of monogenean infestations by appropriate quarantine is preferable to treatment of the parasites after they have become established in a system (Pandey, 1973; Mishra, 2020b).Monogeneans are the most ubiquitous and abundant group of helmith parasites in the aquatic environment. Monogeneans feed upon the blood and cells of ruptured tissues (Bychowsky, 1957; Mishra, 2014c and Mishra, 2015).

The genus Neocalceostoma has been recorded and described in detail from the gills of teleost fishes of super family Siluroidae. Several workers like Gussev (1974); Kritsky,et. al., (1978); Swarup, (1978); Agarwal and Pandey (1981); Kritsky, et. al., (2012) has reported different species of this genus from different teleost as different name. During the study of fresh-water monogenean of district Ayodhya (Faizabad), we came across seven infected specimens of Mystus seenghala, infected with monogenean belonging to the genus Neocalceostoma,Tripathi, 1959. On subsequent study, the present form appears new to us and described here in as such.

\section{MATERIAL AND METHODS:}

The fishes for the present investigation were collected from fresh-water bodies and local fish market of district Balrampur, Uttar Pradesh, India. The monogenean were collected by Mizelle's freezing techniques. They were kept in refrigerator for 8 to 48 hours. The low temperature not only relaxes the worm but also help in automatic removal of mucus in which there flukes were entangled. Subsequently, the gills were removed, placed in separate tubes, half filled with water and shake vigorously. This solution now poured in clean petri-dish diluted with water and examined under binocular microscope. The worms thus collected were washed and fixed in hot $70 \%$ ethyl alcohol or 10\% neutral formalin. Study of chitinoid hard parts were made in either temporary (glycerin) or permanent preparations. Permanent preparations were made after dehydrating through ascending grades of alcohol, clearing in xylene and mounting in Canada balsam. Camera Lucida sketches were made from permanent preparations within a week since the stain fades away in ten days.

\section{GENERIC DIAGNOSIS:}

Body nearly cylindrical, anterior end flattened and expanded, with three pairs of glandular head organs. Two pairs of eye spots. Haptor large, muscular, cup like, wider than body, with a pair of small anchors and 10 marginal hooklets. Intestinal limbs simple, not confluent posteriorly. Testis oval, in mid region of body. Vas deferens passing alongside ovary, seminal vesicle fusiform. Cirrus with accessory piece. A single prostatic reservoir present at base of cirrus. Ovary oval, pre-testicular. Seminal receptacle absent. Vagina tubular, opening toward right side ("vagina median and ventral" according to original generic diagnosis). Vitellaria extending along caeca between pharynx and caecal ends with a break in ovarian zone.

\section{DESCRIPTION:}

The body is elongated with tapering anterior and broad posterior end and measuring $3.23-3.24$ * $0.33-0.36 \mathrm{~mm}$. The head is trilobed having 3 pairs of glandular head organs or pseudo suckers, which appear like phylobothria. The opening of the head organs of the either side are connected with cephalic gland of either side. Two pairs of eye spots are present. The pharynx is well developed, muscular, and spherical in shape and measures $0.15-0.16 \mathrm{~mm}$ in diameter. At the posterior lateral sides of the pharynx, there exists a group of darkly stained cephalic glands. The intestine is simple, bifurcated and intestinal caeca terminate blindly at the posterior region anterior to the haptor.

The testis is single, oval, pre-equatorial, post-ovarian, intercaecal and measures $0.29-0.31$ * $0.20-0.22 \mathrm{~mm}$. A fusiform seminal vesicle is present in the region of copulatory complex and measures $0.13-0.14 * 0.03-0.04 \mathrm{~mm}$. The copulatory complex consists of a cirrus and an accessory piece of cirrus. The cirrus proper is ancoratoid type, long double walled tube like structure and measures $0.071-0.072 \mathrm{~mm}$. in length while the accessory piece of cirrus is slightly bent tube like structure and measures 0.064 $0.065 \mathrm{~mm}$. A single spherical and pear shaped prostate gland is present at the base of cirrus. 
Female reproductive system comprises ovary, vagina and receptacle seminis. The ovary opens at ootype complex, which is situated anterior to it, through a small oviduct. Receptaculum seminis is transversely elongated oval in shape and measures $0.06-0.08 * 0.12-0.13 \mathrm{~mm}$. A common vitelline duct arises from the lateral sides of the body and in the middle they dilate to form ootype complex just above the receptaculum seminis. Vagina is funnel shaped and vaginal duct also opens in the ootype complex. Vitelline follicles are distributed throughout the body from behind pharynx up to the peduncle of the haptor.

The haptor is cup shaped and measures 0.99 $1.13 * 0.45-0.48 \mathrm{~mm}$. Armature of haptor consists of one pair of anchor and ten pairs of marginal hooklets. The anchors are varicorhinus type, with broad and bifid base, curved shaft and recurved at pointed tip. The marginal hooklets are croachet shaped. The details of measurements are:
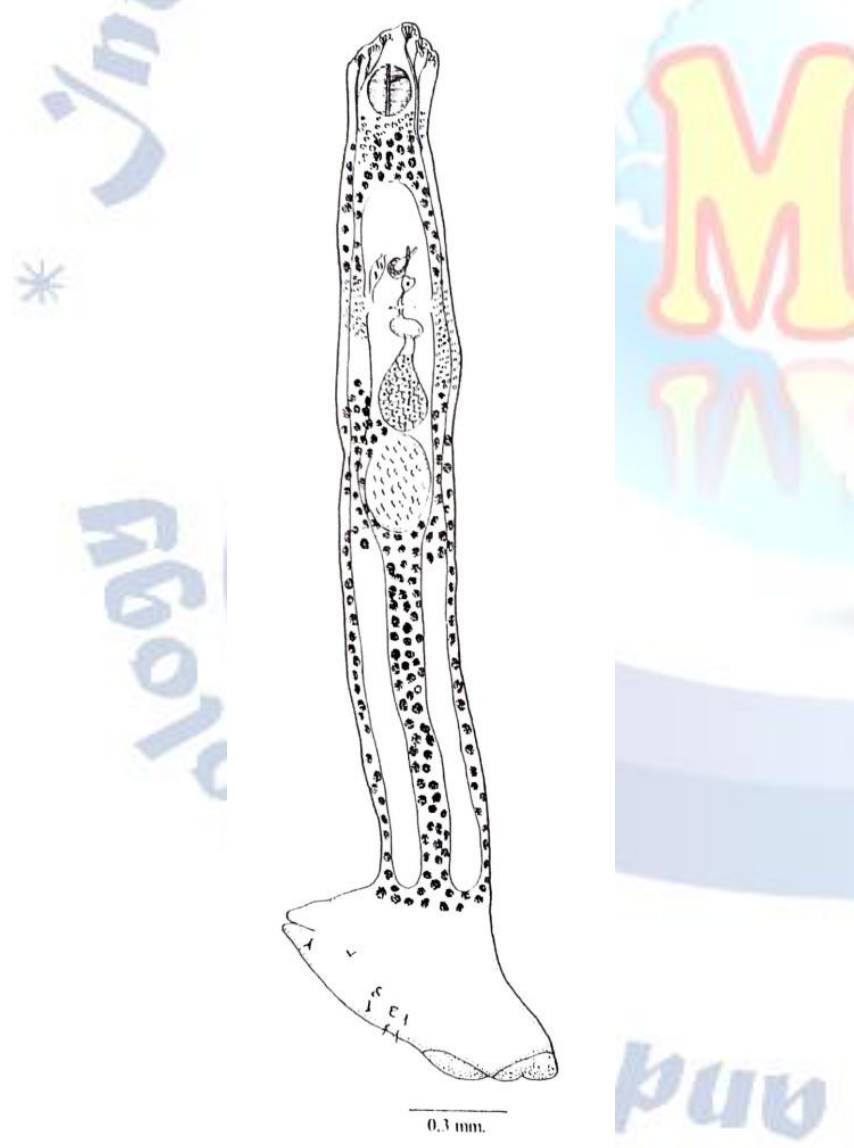

Anchor:

$-0.028 \mathrm{~mm}$

Total length of anchor $\quad: \quad 0.027$

$-0.028 \mathrm{~mm}$

Length of anchor root $\quad: \quad 0.012$

$-0.013 \mathrm{~mm}$.

Length of anchor shaft $\quad: \quad 0.020$

$-0.021 \mathrm{~mm}$.
Length of anchor point :

0.012

- $0.013 \mathrm{~mm}$.

\section{Marginal Hooklets:}

Total length of handle $\quad: \quad 0.010$ $-0.011 \mathrm{~mm}$.

Length of blade

0.012

- $0.013 \mathrm{~mm}$.

Prevalence:Eight specimens of Neocalceostoma from two hosts out of twenty five fish

(Mystus seenghala) examined.

\section{DISCUSSION:}

Tripathi erected the genus Neocalceostoma for the worms collected from the gill filaments of Osteogeneosis militans and Arius aurius with Neocalceostoma elongatum as type species. To the best of my knowledge, two more species were added to the genus viz. Neocalceostoma microformis Swarup, 1978 and Neocalceostoma chauhani Pandey and Mehta, 1986.

The present form differs from all the known species. It differs from Neocalceostoma microformis and Neocalceostoma chauhani in having larger body, difference in ratio of haptor and body, difference in shape of cirrus and gonads. However, it differs from Neocalceostoma elongatum in having different shape of haptor, absence of oesophagus and difference in shape of cirrus. The present form is therefore described as a new species Neocalceostoma guptai n. sp. named in honour of Dr. S. P. Gupta for his valuable contribution in the field of taxonomy.

\section{REFERENCES:}

1. Agarwal, N. and Misra, B. (1994): Mode of locomotion of Neomurreytrema lucknowensis Agarwal and Sharma, 1986 on the gill filaments of Mystus vittatus (Bloch.), fresh water cat fish of district Lucknow. Dr. C. B. Srivastava Comm. Vol. 121 - 127. 2. Agarwal, N. and Pandey, K. C. (1981): On a new monogenean, Wallagotrema chauhani n. sp. from Wallago attu (Schneider). Indian J. Parasit. Vol. 5: 75 - 76.

3. Agarwal, N. and Singh, H. S. (1985): Studies on monogenetic trematodes from fresh water fishes of Gorakhpur, U. P., India. Part I. J. Adv. Zool. 6: 59-61.

4. Bychowsky, B. E. (1957): Monogeneans their systematics and phylogeny (Russian) T. Ransl. English by W.J. Hargis (Ed.), A.I.B., Washington, DC. 626 pp.

5. Chubb, D.K. (1977): Seasonal occurrence of helminthes in freshwater fishes. Part I. Monogenean. Adv. Parasitol., 15: 133-199.

6. Gupta, S. P. (1975): On two new species of the genus Paramazocraes Tripathi, 1959 from marine food fishes of Puri, Orissa. Indian J. Helmith. 18: 4 - 10.

7. Gussev, A.V. and Fernando, C.H. (1973): Dactylogyridae, Monogenoidea, from the stomach of fishes. Folia Parasitol. 20: 207-212.

8. Gussev, A.V. (1974): Fresh water Indian Monogenoidea. Principles of systematics, analysis of the world fauna and their evolution. Indian J. Helmith. 25 \& 26: 1-241.

11 International Journal for Modern Trends in Science and Technology 
9. Hoffman, G.L. (1979): Helmith parasite. In: Plumb, I. A. (ED.) Principal Diseases of Farm-raised Catfish. Southern Cooperative Series No. 225, pp. 40-58.

10. Kritsky, D. C.; Mizelle, J. D. and Bilqees, F. M. (1978): Studies on monogenea of Pakistan part 3 status of the calceostomatidae with a re-description of Neocalceostoma elongatum 1957 and the proposal of neocalceostomoides new genus. Proceedings of the Helminthological Society of Washington Vol. 45(2): 149 - 154.

11. Kritsky, D. C.; Ummey, S.; Kumari, C. P. and Krishnaveni, I. (2012):A new Neocalceostomatid (Monogenoidea) from the gills of the Blackfin Sea Catfish, Arius jella (Siluriformes: Ariidae), In the Bay of Bengal, India. Journal of Parasitology Vol. 98(3): 479 - 483. DOI: 10.1645/GE-3041.1

12. Mishra, Surya Prakash (2007): A new monogenean, Ancylodescoides amethii, $\mathrm{n}$. sp. from fresh water fish Notopterus notopterus. J. Liv. World Vol. 14 (1): 13-17.

13. Mishra, S.P. and Pande, P.N. (2008): A new monogenean MetahaliotremaTripathi $\mathrm{n}$. $\mathrm{sp}$. from fresh water fish Rita rita (Ham.).J.PAS Zoological Sciences Vol. 14: 40-45.

14. Mishra, Surya Prakash (2014a): A new Monogenea Diclidophora srivastavai n. sp. from fresh water fish Setipinna phasa. Int. J. Curr. Microbiol. App. Sci. Vol. 3 (12): 201-204.

15. Mishra, Surya Prakash (2014b): A new monogenean Hamatopeduncularia saketensis n. sp. from fresh water fish Wallago attu. Int.J. Multidis. Res. Dev. Vol. 1 (7): 244-246.

16. Mishra, Surya Prakash (2014c): A New Monogenea Paramazocraes nawabganjensis n. sp. from fresh water fish Eutropichthyes vacha. Int. J. Eng. Sci. Inv. Res. Dev. Vol. 1 (5): 190-193.

17. Mishra, Surya Prakash (2015): On a new species of Monogenea Diplozoon chauhani n. sp. (Diplozooidae) from Indian fresh water food fish Cirrhinus mrigala. Int. J. Fish. Aqua. Stud. Vol. 2 (4): 140-141.

18. Mishra, Surya Prakash (2020a): Monogenetic Trematode Infestations in Indian Cat Fishes of River Gomti at District Sultanpur, Uttar Pradesh, India. Int. J. Modern. Trends in Science and Technology. Vol. 6 (8): 120-124.

19. Mishra, Surya Prakash (2020b): Monogenetic trematode infestations in Indian major carps of Ayodhya division, Uttar Pradesh, India. J. Emer. Tech. Innov. Res. Vol. 7 (7): 1920-1928. 20. Mishra, Surya Prakash (2021a): On a new ectoparasitic Monogenea Rhamnocercus chauhani n. sp. from gills of fresh water fish Wallago attu of district Siddhartha Nagar, Uttar Pradesh, India. Int. J. of All Research Education and Scientific Methods. Vol 9(1): 507 - 510.

21. Mishra, Surya Prakash (2021b): On a new monogenetic trematode Paramazocraes guptai n. sp. from gills of fresh water fish Eutropichthyes vacha of district Gonda, Uttar Pradesh, India. Int. J. Fisheries and Aquatic Research Vol. 6(1): 1 - 3.

22. Pandey, K.C. and Mehta, T. (1986): Studies on some new monogenetic trematode of Wallago attu (Bloch.) at Meerut, Uttar Pradesh, India. Proc. $2^{\text {nd }}$ Nat. Conv. Young Scientists. 114-132. 23. Srivastava, C. B. (1980): Estimation of helminthic infections. Proceedings Workshop Technology Parasitol. Zool. Surveyof India, pp. 29-31.

24. Swarup, M. (1978): A new monogeneaCalceostoma microformis n. sp. from a freshwater fish at Mathura, Veterinary Research Bulletin Vol. 1: 154 - 155.

25. Tripathi, Y. R. (1959): Monogenetic trematodes of fishes from India. Indian J. Helmith. Vol. 9: 1- 149. 